\title{
The development eraser: fantastical schemes, aspirational distractions and high modern mega-events in the Oecusse enclave, Timor-Leste
}

\author{
Laura S. Meitzner Yoder ${ }^{1}$ \\ Wheaton College, USA
}

\begin{abstract}
The array of challenges to durably improving rural peoples' lives in remote regions is so daunting that it can be tempting to erase what is there, and to seek a blank slate. This tension is being played out in the OecusseAmbeno enclave of Timor-Leste, a region long familiar with geographic and political isolation. Residents now encounter a new iteration of their unique status: rapid declaration of their region as a special economic zone (ZEESM), with a new regional governance structure and an appointed leadership. The advent of this new zone is meant to catapult Oecusse from its current state of chronic infrastructure and basic development challenges to a booming economic center and a fount of national income in short order. Early emphasis is placed on rapid, major coastal infrastructure construction deemed necessary for the November 2015 commemoration of the $500^{\text {th }}$ anniversary of Portuguese arrival, with the hallmarks associated with high modernism and mega-event preparation worldwide: spatial re-ordering and regulation; a strong orientation to external inputs, resources, and services; and centralized control of rapid infrastructure change. This article investigates the ideological underpinnings of these plans, and explores the irony of how the proposals and their governance arrangement are a disjuncture with Oecusse as a historically important place. It concludes with observations on this project's place in the national development context, and the likely costs and impacts of development for the Oecusse population. Risks include further political and economic marginalization of the mountain-dwelling and rural population, local residents' loss of productive agricultural land and access to water, reduced protection through administrative exclusion from national political structures, and the opportunity costs of misdevelopment's aspirational distractions.
\end{abstract}

Key words: Special Economic Zone; high modernism; mega-event; Timor-Leste; Oecusse Ambeno; economic development

\section{Résumé}

Les défis à améliorer la vie des populations rurales dans les régions éloignées est si effrayant qu'il peut être tentant d'effacer ce qui est là, et de chercher un nouveau départ. Cette tension se joue dans l'enclave OecussiAmbeno du Timor-Leste, une région longtemps familier avec l'isolement géographique et politique. Les résidents rencontrent maintenant une nouvelle itération de leur statut unique: la déclaration rapide de leur région comme une zone économique spéciale (ZEESM), avec une nouvelle structure de gouvernance régionale et une direction nommée. Le développement de cette nouvelle zone est destinée à catapulter Oecusse de son état actuel de l'infrastructure chronique et défis de développement de base, à un centre économique en plein essor. Le premier accent est la construction de grandes infrastructures côtières, jugé nécessaire pour le 500e anniversaire de l'arrivée portugaise, en Novembre 2015. Cela a des caractéristiques de haute modernisme et la préparation typique pour les méga-événements: réorganisation spatiale et de la réglementation; une forte orientation à des entrées externes, des ressources et des services; et un contrôle centralisé du développement rapide des infrastructures. Cet article examine les fondements idéologiques de ces plans, et explore l'ironie de la façon dont les propositions et de leur système de gouvernance sont une

\footnotetext{
${ }^{1}$ Associate Professor of Environmental Studies, and Director of the Program in Human Needs and Global Resources, Wheaton College, Illinois, USA. Email: laura.yoder "at" wheaton.edu. This article's purpose is to contribute to the ongoing public discussion of how to improve the lives and livelihoods of the rural and urban residents in OecusseAmbeno and Timor-Leste. It is based on ethnographic research conducted in the Oecusse-Ambeno enclave from 20022004 and 2011-2014. In 2013-15 I attended the ZEESM public meetings in Oecusse, and analyzed project documents and media coverage. Recent Oecusse research has been funded by a Wheaton College Human Needs and Global Resources Research Excellence Grant. Sincere thanks to all participants who commented on an early draft at the January 2015 conference, Co-habitations and power dynamics: land, exchange, governance -- contexts for Timor-Leste, in Lisbon, Portugal. La'o Hamutuk researcher Charles Scheiner, Douglas Kammen, and two incisive anonymous reviewers also gave input to sharpen to this article. Its purpose is to contribute to the ongoing public discussion of how to improve the lives and livelihoods of the rural and urban residents in Oecusse-Ambeno and Timor-Leste.
} 
disjonction avec Oecusse comme un lieu d'importance historique. Il conclut par des observations sur le rôle de ce projet dans le développement national, et les coûts probables et les impacts du développement pour la population de Oecusse. Les risques incluent une plus grande marginalisation politique et économique de la population rurale dans les montagnes, une perte de terres agricoles productives et l'accès à l'eau pour les populations locales, leur exclusion administrative des structures politiques nationales qui signifie une réduction de la protection, et les coûts d'opportunité de mal-développement.

Mots clés: zone économique spéciale; haut modernisme; méga-événement; Timor-Leste; Oecusse Ambeno; développement économique

\section{Resumen}

El conjunto de desafíos para mejorar de manera duradera la vida de los pueblos rurales en regiones remotas es tan desalentador que puede ser tentador borrar lo que hay hoy en día allí, y empezar de cero. Esta tensión se ha desarrollado en el enclave Oecesse-Ambeno de Timor-Leste, una región muy familiarizada con el aislamiento geográfico y político. Los residentes ahora se encuentran con una iteración de su estatus único: la rápida declaración de su región como una Zonas Especial economía de Mercado de Timor-Leste (ZEESM), con una nueva estructura regional de gobernanza y un nuevo liderazgo designado. La aparición de esta nueva zona tiene la intensión de catapultar Oecusse desde su estado actual de una infraestructura crónica y retos básicos de desarrollo hacia un centro económico en auge y una fuente de ingresos para la nación en el corto plazo. Énfasis es colocado inicialmente en la rápida construcción de infraestructura costera relevante y estimada necesaria para la conmemoración del 500 aniversario de la llegada de los Portugueses en Noviembre del 2015, esto con los sellos distintivos asociados con la alta modernidad y la preparación de mega eventos en el mundo: re-organización y regulación espacial; una fuerte orientación a los insumos externos; recursos y servicios; y el control centralizado para el rápido cambio de infraestructura. Este artículo investiga los fundamentos ideológicos de estos planes, y explora la ironía de como las propuestas y su acuerdo de gobernanza son una disyunción con Oecusse como un lugar de relevancia histórica. El artículo concluye con observaciones en relación al lugar de este proyecto en el contexto nacional de desarrollo y los posibles costos e impactos de desarrollo para la población de Oecusse. Los riesgos incluyen una mayor marginación política y económica de la vivienda de montaña y la población rural, la perdida de tierra agrícola y acceso al agua de los residentes locales, la protección reducida a través de la exclusión administrativa de las estructuras de política nacional, y los costos de oportunidad asociados a distracciones aspiracionales del mal desarrollo.

Palabras clave: Zona Económica Especial; modernismo; mega-evento; Timor-Leste; Oecusse Ambeno; desarrollo económico

\section{Introduction: unveiling ZEESM}

In early 2013, the government of Timor-Leste ${ }^{2}$ launched a public information project about a fantastical development scheme for the geographically and politically peripheral enclave district of OecusseAmbeno (Figure 1). ${ }^{3}$ Supported by a massive proposed budget allocation of US\$4.11 billion over twenty years (with one third to be provided by the public sector) and initially focusing on an area of just $1.07 \mathrm{~km}^{2}$, plans revealed for the heretofore neglected region included a sweeping overhaul of the institutional, administrative, physical, and economic landscapes (Zonas Especiais de Economia Social de Mercado de Timor-Leste (ZEESM T-L) 2013:5). Near-term initiatives include creating a new governance apparatus and installing an appointed Presidential-level leader for the enclave; plans to replace current infrastructure and erase existing settlement patterns in the very modest downtown to make way for new, clearly demarcated land use zones; and prioritizing the attraction of foreign guests with novel features including golf courses, water parks, and beach resorts where irrigated rice fields now stand. Public presentations and media materials

\footnotetext{
${ }^{2}$ Timor-Leste (East Timor) was a minimally governed Portuguese colony from 1702 until it was abandoned in 1974. Following a struggle between political parties and a declaration of independence, Indonesia invaded the region in 1975 and maintained a military occupation until results from a 1999 referendum under UN oversight separated the nation from Indonesia. From 1999-2002, Timor-Leste was under UN administration, and restored full independence in 2002. The 2010 national population was 1.066m and 97\% Catholic (NSD and UNFPA 2011).

${ }^{3}$ The Oecusse Ambeno exclave, with an area of $815 \mathrm{~km}^{2}$ and a population of 64,025 according to the 2010 census (NSD and UNFPA 2011), is also known as Oecusse (with a wide array of accepted spellings). Following local convention, I refer to the region as an enclave.
} 
about the plans repeatedly emphasize that infrastructure redevelopment will include facilities "of international standard": an airport equipped to land jumbo jets, multi-story hotels, a world-class university to attract students and scholars from abroad, a model hospital equipped to draw medical tourism from all of eastern Indonesia, and features aimed at earning Oecusse a "green city" designation.
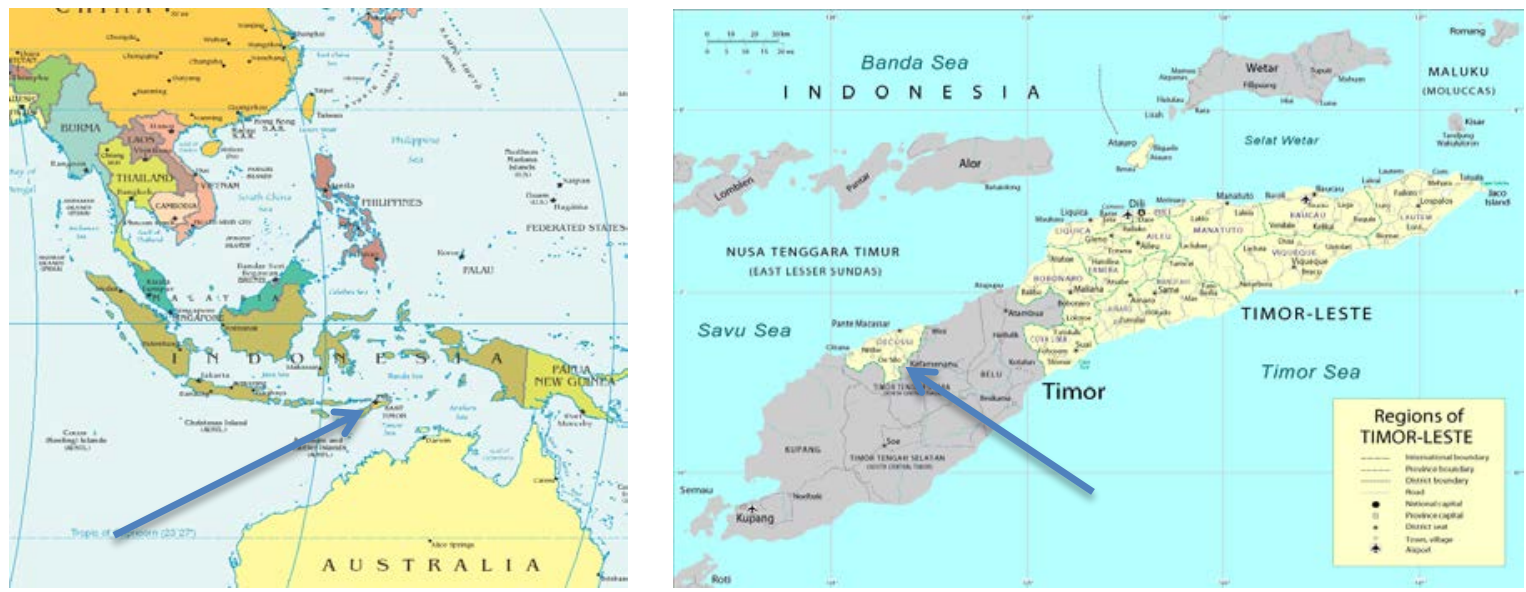

Figure 1: The Oecusse-Ambeno enclave of Timor-Leste, in western Timor (arrows).

Sources: $\quad$ http://printfree.cn/free-printable-maps-political-map-southeast-asia-printables316 (left); http://www.retiredexpat.com/maps/map-timor-leste.php (right).

Through 2013 and 2014, public information sessions for the initiative, that came to be known as ZEESM, took place in the Timor-Leste capital Dili as well as on brief tours throughout the predominantly rural district of Oecusse. ${ }^{4}$ In these sessions, the government-designated state representative to this initiative, former Timor-Leste Prime Minister Mari Alkatiri ${ }^{5}$, showed design diagrams developed by Portuguese economic development consultants and South Korean waterfront development firms. Slideshows in multiple public forums focused on extravagant new facilities, architectural schemata of meticulously zoned urban redesign, and a surreal superimposition of white multi-story buildings and tree-lined avenues (reminiscent of the urban utopia shown and described in Kammen 2009) nestled amidst the precipitously steep, rugged, sparsely vegetated mountains that encircle Oecusse's current downtown. The image in Figure 2 serves as a focal point for the ZEESM publicity, adorning the official project description's front and back covers, featured on large posters erected around Oecusse town, appearing repeatedly in public slide presentations and project videos, highlighted in government documents, and taken up by numerous websites and media sources as emblematic of the initiative.

\footnotetext{
${ }^{4}$ The ZEESM acronym is Portuguese: Zona Especial de Economia Sosial de Mercado (Special Economic Zone of Social Market Economy). It is frequently pronounced "ZEEMS", which is also the Tetum-language acronym (Zona Ekonomia Espesiál Merkadu Sosiál). This term originated with German economic approaches developed in the late 1940s that prioritize free market capitalism toward the end of social development with minimal governmental oversight. The term "social market" does not appear in the government's 2011-2030 national Strategic Development Plan (Republica Democratica de Timor-Leste 2011).

${ }^{5}$ Dr. Mari Bim Amude Alkatiri was Timor-Leste's Prime Minister from 2002-2006. Raised as part of Dili's tiny Muslim community and following university education in Angola, Alkatiri left Timor in 1975 on a political delegation and spent decades based in Mozambique and Angola, as a surveyor and legal consultant, and was active in political advocacy. He returned to Timor in 1999 and has maintained a high national political presence. He began consulting outside specialists regarding this project from 2010, and publicly launched it with an entourage on his socialization visit in May 2013 (ZEESM 2013; Gabinete da Ex Primeiru Ministro Dr. Mari Alkatiri 2013). His leadership has shaped closely the ZEESM initiative. As chief spokesperson and highly visible champion of the project, he is cited often throughout this article for his public presentations and appearances in the media.
} 


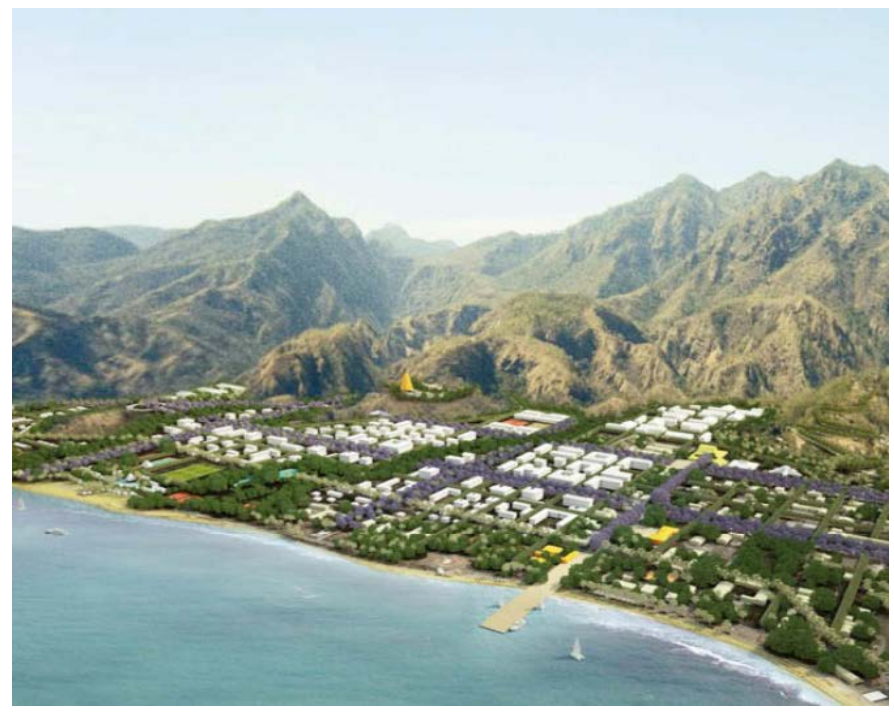

Figure 2: A transformative vision for Pante Makassar, a high modern Oecusse city. Source: http://opinitimor.blogspot.com/2014/04/lei-zeesm-laos-fasil.html

Fulfilling the 2002 Constitutional mandate that the Oecusse Ambeno enclave "shall enjoy special administrative and economic treatment" and "shall be governed by a special administrative policy and economic regime," ${ }^{6}$ this special economic zone was formed by rapid action of the national Parliament in approving a special autonomy regulation. In May and June $2014^{7}$, the National Parliament passed and TimorLeste President signed a law which established the Special Administrative Region of Oecusse Ambeno (Tetum acronym: RAEOA) and declared the Special Zone of Social Market Economy. ${ }^{8}$ This 'pilot project' is the first special economic zone to be implemented among the six National Strategic Zones envisioned in the national Strategic Development Plan (Agência Lusa 2015; Republica Democratica de Timor-Leste 2011:114116). Formalizing his role as early leader and visionary for this initiative, Mari Alkatiri was appointed as President of the Authority of the RAEOA on 25 July 2014. ${ }^{9}$ The initial leadership team was to consist of seven appointed members (Presidency of the Council of Ministers 2015). ${ }^{10}$ On 25 January 2015, district governance was formally handed over to the RAEOA (Agência Lusa 2015; Pereira 2015), and the national 2015 budget awarded US\$81.93 million to the ZEESM Authority in January 2014, increased to US\$133.4 million with a budget revision in March 2015. ${ }^{11}$

This sudden attention was a dramatic departure from the treatment Oecusse has long received, as a neglected peripheral district rarely visited by national government officials and poorly accessible by land, sea, or air to would-be visitors. The district has persistent difficulties in improving basic human development

\footnotetext{
${ }^{6}$ Section 5, Clause 3 and Section 71, Clause 2, respectively.

${ }^{7}$ Article 19.1, of Law no. 3/2014, of 18 June 2014.

${ }^{8}$ Note that the ZEESM zone includes Ataúro island which is nearby Dili, but the RAEOA does not.

${ }^{9}$ Presidential Decree no. 22/2014, of 25 July 2014.

${ }^{10}$ Initially appointed members included Alkatiri plus a team of three: a Dili-based project manager of Oecusse extraction who is a former national Parliamentarian and Minister of Labor and Community Reintegration, an administrative and financial overseer, and the land and property specialist who formerly directed the national land department (Presidency of the Council of Ministers 2015). The Council of Ministers decision directed Alkatiri to nominate additional members; on 10 June 2015, four members were added and the RAEOA installed seven Regional Secretaries in these areas: Education and Social Solidarity, Health, Administration, Finance, Agriculture and Rural Development, Community Tourism, and Regional Planning and Cadaster. Three of the seven are women.

${ }^{11}$ This budgetary outlay occurred with simultaneous decreases in national public spending for water, education, and health (La'o Hamutuk 2015). For ongoing analysis of the economic and policy aspects of the ZEESM initiative, see the La'o Hamutuk website (www.laohamutuk.org). Updated state budget information is found at http://www.laohamutuk.org/econ/OGE15/14OGE15.htm\#ret.
} 
indicators and remains low in national rankings (NSD and UNFPA 2011). Fully 46.6\% of the Oecusse population is in the lowest household wealth quintile, by far the highest of any district. Oecusse also remains at the bottom nationally in literacy and at the top in teenage pregnancy (National Statistics Directorate (NSD) [Timor-Leste] and Macro 2010:27-28, 35-36, 58). Oecusse's claim to national fame is historical, residing mostly in its status as landing spot of the Portuguese, with the 500-year commemoration celebration scheduled for November 2015. The flurry of public meetings, media presentations, and written materials pertaining to this new initiative presage an imminent leveling of existing public infrastructure, in-town settlements, and local land ownership patterns in what has suddenly become premium real estate in the diminutive downtown, in order to make way for high-rise construction projects deemed foundational to the economic jump-start of this transformational endeavor. The economic model of export-oriented processing, high-end tourism, and industrial production in special economic zones worldwide is ironically at odds with Oecusse's national reputation for strong traditionalism (Zonas Especiais de Economia Social de Mercado de Timor-Leste (ZEESM T-L) 2013:56). How are Oecusse people and outsiders navigating the appearance of this aspirational project, and being catapulted from persistent administrative neglect to a new position on center stage, amidst the rhetoric of making the enclave an economic powerhouse of the nation through attracting private investment (Gabinete da Ex Primeiru Ministro Dr. Mari Alkatiri 2013)? How do project design and early implementation set the trajectory for the long-term social, economic, and ecological impacts that such an approach is likely to have on the local population?

This article excavates the development approaches that underlie and frame the ZEESM initiative. The effects of high modernist development on a local population are profound. In this case, far-reaching change is planned and is also deliberate. It demonstrates a certain kind of selective appreciation for the past, choosing the aspects of culture and history that do not threaten or stand in the way of modernization. The enclave has a long tradition of isolation and de facto autonomy, yet is self-fashioned as cosmopolitan for its famous historical encounters with the outside world. I consider how enacting the classic suite of high modernist practices (Scott 1998) of zoning and spatial reordering, control by outside technical experts, and projects oriented toward external beneficiaries not only obscures but has the effect of erasing Oecusse's specificity of place. Given the precipitous project initiation, hasty infrastructure construction, and the expansive aspirations toward re-ordering spatial and socio-economic relationships within the district, we can view the near-term preparations for the celebration of Portuguese arrival to Timor and the greater ZEESM vision as a mega-event on the Oecusse stage. The lessons learned from long-term economic risks and sociopolitical outcomes of mega-events can inform analysis of initiatives that envision regional development primarily in technical and physical terms. The article concludes with reflections on the pervasive persistence of misdevelopment, in Timor and beyond.

\section{Isolated cosmopolitanism: political history of Lifau in the national imaginary}

Oecusse's fame is singular and lies in its distinctive history: nestled among rice fields is Lifau ${ }^{12}$, a coastal location several kilometers west of Pante Makassar town and memorialized as the original landing spot for the Portuguese to Timor Island in the year $1515 .^{13}$ Local people and outsiders alike make frequent reference to the historical importance of the region as Portuguese Timor's first capital, as a notable feature in itself and as lending special status to the region in the national imaginary. Although Lifau was well known to be visited by Chinese traders seeking Timor's renowned sandalwood and beeswax for centuries before Portuguese arrival, Lifau's role in supplying trade items has not come to be a marker of identity and national pride. $^{14}$ Rather, it was the arrival of Catholicism, and the early association with what came to be the

\footnotetext{
${ }^{12}$ Parada (1974:557-559) noted that the name Lifau was derived from the Meto lé'àl (people) faun, nanfaun (many), or many people. It earned the name énò naek, or 'great door', because there was so much trade along the coast. Daschbach described Lifau as taken from the Meto liatnamfau neitin, many friends who come to talk (1992:46).

${ }^{13}$ There is scant historical evidence to support the precision of the 15 August 1515 landing date inscribed on the Lifau monument, but that matter is the subject of a different discussion. In the lead-up to the 2015 celebration, a few Oecusse family groups have contested whether Lifau was actually the first landing spot, claiming supernatural evidence of their own Portuguese ancestors arriving at other points along the Oecusse-Ambeno coast before Lifau.

${ }^{14}$ Names of seasonal settlements of Asian traders who stayed in Oecusse until the winds shifted persist in Oecusse today, in the regional Malay trade language. Kolam Sina (Chinese pool) is just west of Lifau, and Pante Macassar (Makassar beach) is east of Lifau, once a large colony of seasonal sandalwood traders that still lends its name to the subdistrict containing Oecusse's capital town (Gunn 1999:103). For centuries, Chinese traders were the only non-Timorese who
} 
Portuguese colonial relationship, that makes this mark. Oecusse's population is of the same ethno-linguistic group as in surrounding (Dutch/Indonesian/Protestant) West Timor, but it was the enduring colonial affiliation that accounts for Oecusse's current status as a political enclave of Timor-Leste. The ZEESM Master Plan situation analysis (Zonas Especiais de Economia Social de Mercado de Timor-Leste (ZEESM TL) 2013:51) glosses the relationship thus: "Lifau is a sacred place for the people of Oecusse, as a place of cultural heritage and historical significance. The Catholic religion began here, as did modern political administration. The City of Lifau was the first urban center from 1702 to 1769 of what is now Timor-Leste."

Oecusse's historic association with Portuguese governance and the entry point of Catholicism remain significant modern points of pride among Oecusse people. Invoking these aspects of identity has played a large role in media and public presentations concerning ZEESM. Mari Alkatiri's speeches and publicity statements echo a common refrain among Oecusse people: "Timor-Leste began in Oecusse; without Oecusse, there would be no Timor-Leste" (RTTL 2013). Alkatiri further buttresses the political value of Oecusse to the nation by stating that $99 \%$ of Oecusse people voted against remaining with Indonesia during the 1999 referendum (RTTL 2013). ${ }^{15}$ History provides the justification for their enduring identity as part of Portuguese/East Timor, even as it relegated them to an enclave, peripheral to central administration and relatively neglected by Dili-based governments. Alkatiri highlights this special status of the isolated enclave, with its Constitutional provision for a special regime, as the reason for choosing to launch the national Special Economic Zone program in the district (RTTL 2013; ZEESM 2013).

The Portuguese-Oecusse encounter figures largely in verbal and visual portrayals of the district. Large banners on display throughout town in 2014 publicizing the current ZEESM initiative, including an eventual Museum, featuring various artistic renditions of a coastal encounter between clerical Europeans arriving from ships and Oecusse native men (identifiable by the typical calf-length woven garments, approaching from a dense forest; see Figure 3). In a context where precedence and history are deeply valued, these portrayals serve an important role in furthering the socio-political importance of the ZEESM initiative: Oecusse people are the guardians of this heritage, and it is their responsibility to ensure that the 500 -year commemoration of this monumental event occurs smoothly and with proper facilities for guests, including early official document and media mentions of hopes that the Pope would attend the ceremonies.
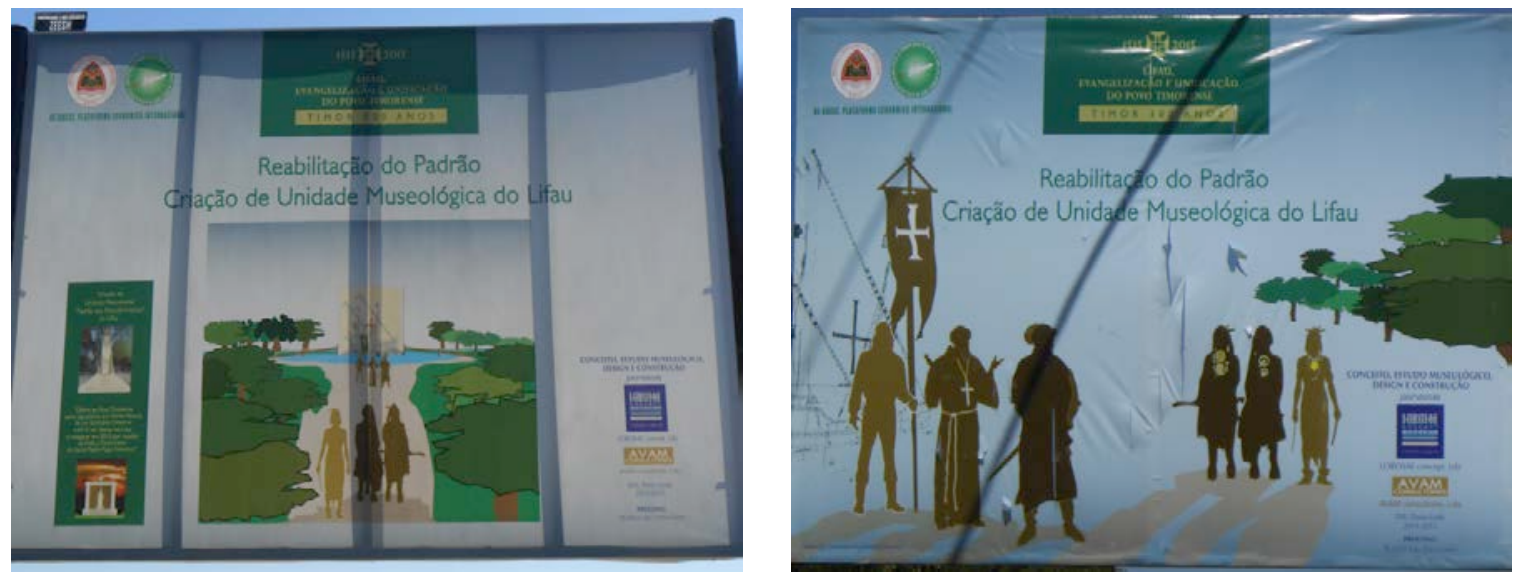

Figure 3: These large banners with the heading "Lifau: evangelization and unification of the Timorese people" were among the many designs displayed in Oecusse town during 2014. The upper left logos are of the Timor-Leste government and ZEESM. The lower left image on the left poster is of a new monument planned for Lifau, to be "inaugurated on the [anticipated] 2015 visit of Pope Francis to Timor-Leste." Source: Photos by the author.

traveled throughout Timor's interior (Fox 2000:18-19), even at significant personal risk (Ormeling 1956:132-135), and Portuguese travelers mentioned frequently the presence of Chinese residents in Oecusse (Vaquinhas 1883; Oliveira 1950:282, 284; Teixeira 1974b).

${ }^{15}$ This figure is overstated and unknowable, as referendum votes were only reported in national aggregate. 


\section{Showcasing Oecusse as Portuguese, Catholic, coastal, and urban}

Selective portrayals of a Lifau-centric Oecusse history as Portuguese, Catholic, coastal, and urban serve to convey a tidy, if inaccurate, view of the district as one with enduring, unwavering loyalty to Portuguese rule, with the modern nation-state of Timor-Leste as its telos. This narrative is congruent to the avid efforts toward Lusification of recent years in some quarters, but it neglects important Oecusse realities and patterns that are germane to the topic of Oecusse's autonomous governance. Focusing on Portuguese connections obscures the history of local authorities' variable loyalties to Portuguese alliance, with centuries of political ambivalence on both sides: the part-European ${ }^{16}$ leaders were notoriously resistant to colonial rule (Boxer 1947; Durand 2002), strong Oecusse figures chased out the Portuguese government in 1769 (Hägerdal 2012), and the question of keeping the enclave within the colonial enterprise was revisited multiple times in recent centuries (Correia 1933; Martinho 1945; Oliveira 1950). Neglecting this variability ignores the historically strong local authorities who have long been at the center of Oecusse's political organization in the near-absence of a distant state's attention, and overlooks the fact that even until today, much of Oecusse life is conducted in the context of a relatively absentee state.

Importantly, this officialized gloss of Oecusse history also serves to focus attention on the coastal lowlands, which were relatively unpopulated until the late 1980s when Indonesia promoted coastward resettlement in Oecusse as it did throughout East Timor (United Nations Development Program 2002). Although Timor's arid north coast is less agriculturally favorable than the richer soils and more abundant rainfall of the southern interior highlands, this relocation was done by force to enable surveillance, or by persuasion by geographically limiting the provision of services. The difficult-to-navigate mountain towns and rural hamlets, still inaccessible by road for much of the year, remain home for most Oecusse people, where the majority of the district's population continues to practice rainfed subsistence swidden agriculture that is still mediated by rituals and oversight of customary natural resource authorities (Meitzner Yoder 2007b, 2011a, 2011b). Mountain areas remain the focal point of many coastal dwellers' lives; family, fields, and ritual houses and sacred sites are still in the highlands. Schoolchildren who move to town for education, often without their parents, return periodically to their mountain homes to carry upland corn and other foods down to their coastal houses. Lowland residents return to their highland home areas for annual agricultural rituals, sacrifices, and special events.

Oecusse is long familiar with external agents that barely penetrate the mountains. Colonial powers faced crushing military defeats by local leaders in Timor's mountainous interior, and as a consequence colonial state representatives rarely ventured there. While Oecusse lowlanders assume for themselves a certain cosmopolitanism by virtue of their own long history of contacts with multiple classes of outsiders, outsiders' knowledge of Oecusse's interior remains sparse to this day. Writers commented that no Portuguese was ever known to have crossed the region by the late 1800s (Dores 1901:774, 812). The Catholic Church spread was slow, and long confined to the lowlands as well. Sporadic and thin Church presence yielded few converts; census figures indicate a gradual, localized, and coastal increase in church membership, until a rapid increase only during the mid-twentieth century. ${ }^{17}$ In the 1860 s, the Father Barreto, Superior of the Oecusse mission, taught many local people to read and write, and he travelled to the interior to conduct

\footnotetext{
${ }^{16}$ Hägerdal's masterful history notes that neither of the most written-about Oecusse families were of Portuguese descent (2012:140-141). The Hornay line came from a Dutch civil servant who may have been of Danish descent, and da Costa was a Papanger from the island of Luzon, Philippines. "The fact that the Hornays and Da Costas had different ethnic backgrounds, neither of them Portuguese, proves once more that racial features did not determine one's position in the Larantuqueiro community - anybody with ambition could rise to a position of importance" (141).

${ }^{17}$ The presence of the Church on Timor remained sparse and declined during the 1700s. Mission activities centered on education. The bishop of Malacca founded Timor's first seminary in Lifau in the 1730s (Gunn 1999:76; Martinho 1945:187), but it faltered due to local strife and regional warfare, lack of support sent from the central authorities, and, "more than all this, the discord between military and religious authorities for temporal power" (Martinho 1945:187). The religious orders were expelled from Timor briefly in 1834 (Martinho 1945:187). Church estimates from 1882 indicate that Oecusse-Ambeno was 12\% Catholic (Ferreira 1902). The Church reported a strong movement of conversion after the Japanese occupation of the Second World War, and in 1954 identified 39\% of the Oecusse population as Catholic (Procuradoria da Diocese da Dili em Lisboa 1956:xix). In 1956 when the Catholic Church published the first catechism in the local language, Oecusse had 3 priests, 6 Dominican nuns, and 41 indigenous catechists, with two Church schools educating 86 male and 88 female students (Procuradoria da Diocese da Dili em Lisboa 1956:xx). Between 1941 and 1972, under the leadership of one priest, Norberto Parada, the Catholic population increased to 19,000, about $76 \%$ of the population (Teixeira 1974a:482).
} 
baptisms (Oliveira 1950:56). Daschbach (1987:8) credited the priest Norberto Parada with making the first concerted efforts to reach mountain-dwellers in the 1950s, including establishing lowland Oecusse people as the first in-residence missionaries to highland regions, in a period when a subdistrict administrator only travelled throughout the region with a team of armed guards. In the early 2000s, elder residents of many interior hamlets stated that no Portuguese or Indonesian government agent had ever entered their area; some long-time civil servants had their first visits to major interior villages only in 2003.

Portraying a sparse, coast-focused history justifies the coastal centricity of the ZEESM economic development and infrastructure investments, which in public presentations are barely envisioned to extend beyond view of the ocean. In notable contrast to the extensive homage given to coastal Lifau and Pante Makassar in project rhetoric and initiatives, Oecusse's interior highlands remain as marginalized in official recognition as they are in regional development investments. As long as the logistical challenges of rural development are ignored by not engaging rural areas, these regions remain out of sight and beyond the reach of services that may increase the positive benefits of the ZEESM expenditures on rural lives and livelihoods. In mid-2014, I talked with a mountain dweller about what changes he anticipated as a result of the new initiative beginning in the district. He had attended public information sessions, but said he was no longer paying much attention to the project, because "the project is only for town; ZEESM is not for mountain people."

ZEESM is not the first plan for a special governance regime in post-independence Timor-Leste. Political autonomy can occur de facto with central government neglect, and Oecusse's isolation has long fostered strong local leadership, both in customary and local political realms. Enclave residents well recognize the importance of special regulations to the flourishing of their region. After separating from Indonesia in 1999, when the enclave felt the devastating effects of a hard border regime and economic isolation for the availability of food and other staple goods, leaders who lived in Oecusse crafted multiple documents advocating and outlining options for implementation of the Constitutional guarantee of special administrative and economic treatment. Softening the border regime to simplify travel and trade relations with Indonesian West Timor and improved external communications have been among the top priorities of local political representatives in Oecusse since 1999 (Bano and Rees 2002). In Timor-Leste's early years, a locally appointed Oecusse team that drafted an implementation plan for the enclave's autonomous status proposed that Oecusse should be governed according to the existing customary administrative divisions and leadership institutions, noting roles for national law, [Catholic] Church law, and adat (customary) law (Anuno and Muni Salu 2003). While this proposal reflects governance expectations more common in TimorLeste a decade ago, it puts forth a strong role for structures grounded in Oecusse life-in contrast to a standardized ideal model not only imported from the international arena of special economic zones, but bearing the deliberate placelessness that could be anywhere. The vision declared by fiat of Dili-based leadership, about which Oecusse people were informed more than consulted, embodies a different vision of regional autonomy than what these local leaders proposed a decade earlier.

\section{Social engineering and reinventing a high modernist model city}

Economic development in remote rural contexts requires such persistent, multi-faceted attention that it is not surprising that many development actors seek simplifications to identify and to implement shortcuts to progress. Putting faith and funding in magic bullets, international agencies and national governments alike are lured into pursuing a wide range of fantastical projects that are doomed by their unrealistically excessive ambition as much as their ill-suited methods. Timor-Leste has been subject to a dazzling array of development projects aimed at ambitiously scaled and often fast-paced reductions in widespread poverty. A small sampling includes inter-island transmigration programs under Indonesia (Taylor 1999a), a World Bank-funded socioeconomic development effort during the era of United Nations oversight in the early 2000s that introduced an often problematic parallel governance structure (Kingsbury 2012; NDPEAC and MoPF 2004), and serial efforts at land formalization from the UN era that have recurred under the presentday Timor-Leste government (Batterbury et al. 2015; Rede ba Rai 2013). Similarly grandiose plans have appeared for Timor-Leste's state-owned oil enterprise and multiple recent infrastructure programs that did not approach their stated objectives (La'o Hamutuk 2012; Wallis and Thu 2013). Many of these megaprojects have laudable stated goals, such as increased community participation in local economic improvement and 
decentralization to provide public services to remote regions and vulnerable populations. Many program leaders are personally committed to seeing improvements in quality of life, and (as in the case of Oecusse) they are implementing these plans in their own home communities, among their own friends and families. So why and how do these projects not demonstrate good outcomes?

At the outset of Seeing like a state: how certain schemes to improve the human condition have failed, James Scott discusses four elements of state-initiated, utopian social engineering that explain why even wellintentioned initiatives often fail to improve the lives of people (Scott 1998:4-5). They are:

1) An "administrative ordering of nature and society" that prioritizes simplifying the work of statecraft above all else;

2) an ideology of "high modernism", which anchors the following discussion;

3) authoritarian state leadership, often related to revolutionary tendencies and social designs; and

4) a weak civil society that does not oppose or resist the imposition of utopian plans upon their lives and land.

Taylor notes that high modernity has no patience for organic, emergent developments, but rather seeks to create a blank slate in order to effect total transformation of a place (Taylor 1999b). The variability and complexity inherent in human societies defy the regularization of high modernism.

This analysis focuses on Scott's second aspect. Scott (1998:4) characterizes high modernism as having extreme "self-confidence about scientific and technical progress, the expansion of production, the growing satisfaction of human needs, the mastery of nature (including human nature), and, above all, the rational design of social order commensurate with the scientific understanding of natural laws." It is a byproduct of industrial progress. He describes high modernism as "uncritical, unskeptical, and thus unscientifically optimistic about the possibilities for the comprehensive planning of human settlement and production" (4). The aesthetics of high modernism are highly visual with an emphasis on geometric rationalization, and favor the miniaturization allowed by the "more easily controlled micro-order in model cities" (4). High modernist advocates and practitioners are most often powerful officials who demonstrate strong interest in social planning; their allies are the scientific and technical experts whose skills are central to the literal and figurative building of the utopian enterprise.

The ZEESM project aspires to thoroughgoing socio-economic engineering, seeking to transform multiple aspects of life in grandiose proportion. As represented to Oecusse people through public meetings and to a wider audience through media, documents, and presentations, implementers are forthright and detailed about how this initiative seeks to transform existing norms and practices through a radical reordering of land, society, and economic relations. Early and later planned phases demonstrate characteristics of high modernism's ambitions on the physical landscape to meet some purported social and economic ends as outlined by Scott: deliberate focus on spatial re-ordering through land use zoning; a high reliance on technical and bureaucratic experts; and strong orientation to external input, resources, and services.

\section{Spatial re-ordering and dispossession of Oecusse residents' land}

Always a central feature of high modernist planning, the need for spatial reordering of Oecusse's town and surrounding lowland areas is repeatedly portrayed as foundational to the whole ZEESM endeavor. In a succinct, Tetum-language message about the project, Alkatiri states that the first impact of ZEESM will be on land, since the project will need to use land (ZEESM 2013). He also states that Oecusse people will need to change the view they have of their land, toward something having productive potential and a resource that can provide ongoing income (RTTL 2013). ${ }^{18}$ To resolve issues that arise around (public or private) use by the project of Oecusse residents' private land, Alkatiri proposes the following resolution:

\footnotetext{
${ }^{18}$ Several recent studies (Fitzpatrick, McWilliam and Barnes 2012; McWilliam and Traube 2011; Rede ba Rai 2013) give ethnographic detail on the cultural conceptions of land, the importance of place and memory, resource-dependent livelihoods, and the interplay of political authority and historical claims to land that are deeply embedded in Timorese life
} 
If the whole project need[s] the land, instead of paying to the landowner money, the landowner will be invited to be an investor to the whole project. He will feel part from [sic] the whole project. His land will be valued, and will be converted into titles. This is a financial scheme that we are going to develop (Gabinete da Ex Primeiru Ministro Dr. Mari Alkatiri 2013).

As Timor-Leste has not had a functioning comprehensive land policy or body of laws enabling land titling since 1999, this is a politically and legally ambitious initiative. Presumably, the new mechanisms might also provide land titles to individuals whose land is not being acquired by the ZEESM project; however, the cadastral urgency clearly centers on state land acquisition for imminent projects rather than a district-wide initiative on registration of privately held land. This reproduces the post-1999 official land practices in Timor-Leste, which over-privilege state claims and give relatively little priority to private claims - and virtually ignore the status of customary land and claims in rural regions of the nation. As such, land acquisition will be conducted under time pressure in the absence of robust rural or urban land policiesa scenario familiar in places subjected to mega-event development, discussed below.

The land use zoning that marks clearly the areas from which many households would need to be relocated to suit idealized urban designs, while developed by external consultants, was openly publicized within Oecusse in public presentations and on posters (Figure 4). Urban planning schemata of Pante Macassar's downtown (Figure 5) have also been widely presented in meetings for potential donors, government officials, and the public. Accordingly, land issues have been foremost in Oecusse residents' minds; the village leader for the most-affected village (Costa) expressed concern for the houses, forest, and other aspects within the road-widening zone and other project construction areas (2015c). Several hundred people attended the 23rd May 2013 public presentation of the master plan for the entire day. ${ }^{19}$ During the morning question-and-answer session, most of the questions posed to the visiting delegation concerned various aspects of land use, appropriation, rent payments, acquisition processes, and contracts; question after question, the topic was raised so repeatedly that after some time, it was announced that enough questions about land had been addressed, and that only questions on other topics would be permitted for the remainder of the forum. The matter of what would happen to land acquired by the project, in the event that the planned public uses did not materialize, was raised by residents but not answered in the session.

The ZEESM vision initially seeks to transform Oecusse by promoting urban-based industries and services, and rearranging the current town capital according to well-defined land use zoning following a grid system (Figure 5). Public presentations indicate the leveling of existing single-storey downtown offices, in order to make way for larger, new ones like the multi-story structures shown in the Singaporesque diagram of the envisioned city (see Figure 2) ${ }^{20}$ In July 2014, the ZEESM staff presented the two major proposals received to date, featuring both organizations' visual representations of their designated business, industrial, residential, recreational, cultural, and tourism zones, for the coastal area the immediate vicinity of Pante Macassar town. ${ }^{21}$ These urban and regional planning proposal diagrams were also displayed on the large publicity posters around Oecusse town during 2014, and many residents noted with dismay that their current homes were within a zone designated for industry, transport, commerce, or other categories that would require their relocation. Several civil servants noted that most staff in their various offices (including themselves) would have to move their places of residence to accommodate the new zoning plans. Whether these plans come to fruition or not in any form, their repeated public use by ZEESM officials communicates significant messages about the new regional government's vision of the future for Oecusse's land and people.

and identity across the nation, including Oecusse (Batterbury et al. 2015; Meitzner Yoder 2011b). All these studies make eminently clear that changing one's relationship to the land is more complex than an intellectual or economic decision.

${ }^{19}$ A ZEESM publicity video states that almost 1,000 inhabitants attended this May 2013 meeting (Gabinete da Ex Primeiru Ministro Dr. Mari Alkatiri 2013).

${ }^{20}$ Land without existing construction or agricultural use is present in the lowland region. However, with the exception of the two envisioned resort complexes, I found no mention of constructing a city from scratch in a different location than the current town capital, Pante Macassar.

${ }^{21}$ The two organizations featured were described as follows: "Lusitania Foundation for University and Entrepreneurial Development (FLD), a Portuguese non-profit organisation that specialises in developing economic zones", and "KUNIL Engineering Co. Ltd, a South Korean company which strives to create environmentally friendly living space and constructing indirect social infrastructures" (Bano 2014). These organizations' products are shown in Figures 4, 5, and 6 of this article. 
These diagrams convey a picture in which the land use priorities and agenda are set by outside technical experts, and existing residents and both built and natural features may be removed or reordered at will.

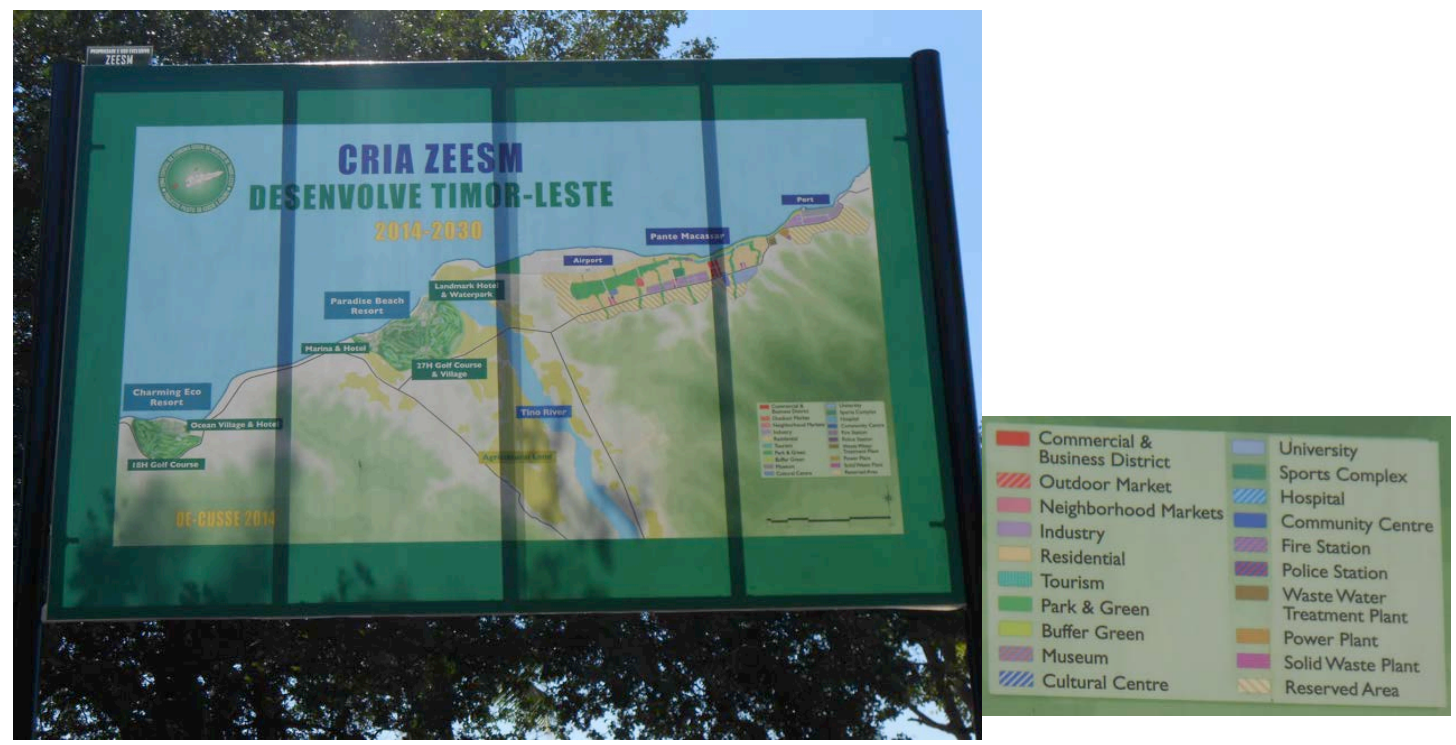

Figure 4: Proposed land use zones as publicized on large posters placed around Pante Macassar town in Oecusse in 2014. The poster focuses on this coastal area spanning 18 of Oecusse's 55 kilometers of coastline, and shows plans for less than $3 \%$ of Oecusse's total land area; the mountainous southern interior, invisible here, has no readily apparent place in the 2014-2030 plan. The English-language key does not indicate that Oecusse residents are the primary intended audience for this information about the regional development plans. The two coastal green patches on the left half are proposed resorts. Source: Photo by the author.

In contrast to the detailed grand (re)designs on Pante Macassar town, the proposals are remarkably unambitious and vague in their geographic reach to the rest of Oecusse outside this narrow area. It is striking that the development plan and governance attention for a largely rural, upland agrarian district initially focuses on intensive construction in a coastal area named in project documents to cover just 1.07 square kilometers. ${ }^{22}$ This zone is anchored in the current downtown of Pante Macassar, and extends a few kilometers in both directions along the coast, spanning approximately eight kilometers from the Mahata port to the east to the Lifau monument site just past the Palaban airstrip to the west. This lowland town area and surrounds currently contain about $9-14 \%$ of Oecusse's total population, and the vision is to expand this fiveto six-fold within a few years of the ZEESM's first phase. ${ }^{23}$

\footnotetext{
${ }^{22}$ This replicates the apparent blindness, or ambivalence, of the state to the land access needs and practices for rural regions across Timor-Leste, evident from the UN era and persisting to the present (Batterbury et al. 2015; Fitzpatrick, McWilliam, and Barnes 2012).

${ }^{23}$ ZEESM-related sources cite the Oecusse population in the range of 58,500 (FLD 2013) to 74,000 people (RTTL 2013). The current population of the area of Oecusse town to be targeted by new urban initiatives is 5,000-10,000. Alkatiri anticipates that the new Oecusse city will bring 30,000 in the early phases, and up to 150,000 people in the imaginable future-a scenario that he characterizes as necessary to speed up urban development by expanding the market base (Gabinete da Ex Primeiru Ministro Dr. Mari Alkatiri 2013). The South Korean waterfront development firm materials give a 2013 base population of 10,000 for Pante Macassar town, and project 63,000 by 2030 (Kunil Engineering Co. 2014).
} 


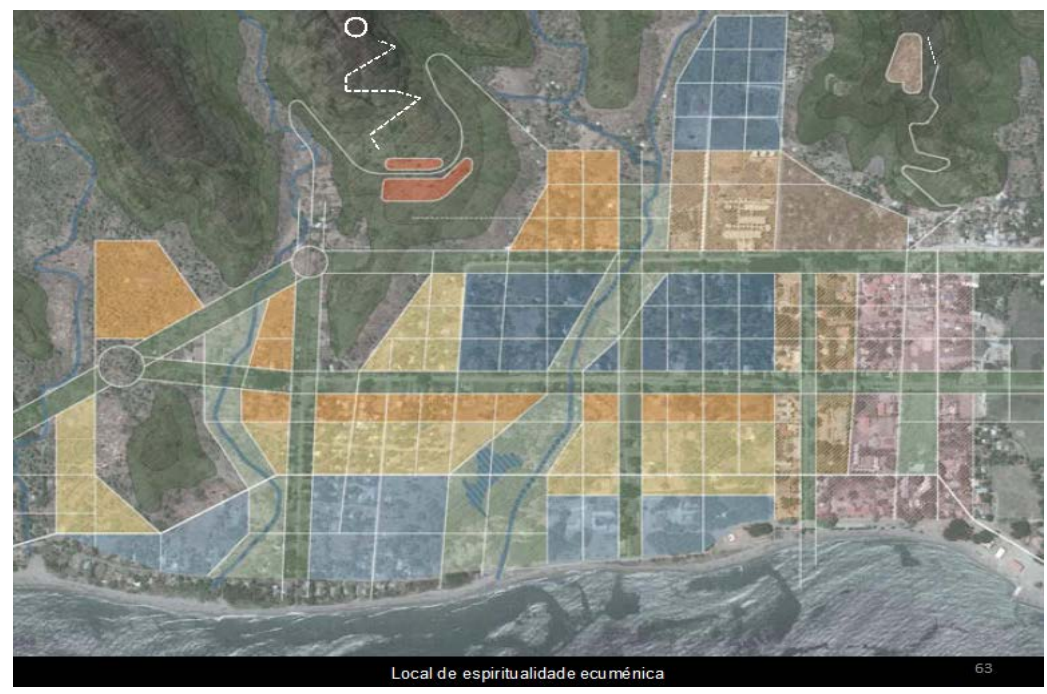

Figure 5: Urban planning design for Oecusse's downtown would require substantial relocation and transform current land uses. There are designated blocks for various land use zones, as well as designation for two-, three-, and four-story buildings. In late 2015, there is little evidence to suggest that ZEESM implementation is following this plan as it was proposed in detail. Source: FLD Master Plan, March 2013, available at http://www.laohamutuk.org/econ/Oecussi/MasterPlanFLDMar2013.pdf [accessed 30 August 2014].

This high modernist approach of near-exclusive focus on a miniature model city replicates the earlier national focus on the relatively small urban area of Dili, to the neglect of the rural majority. The ZEESM plan does include much-needed attention to addressing education and health in the district, but the focus is on coastal facilities — not services or personnel—and centered in town — not increasing rural access for mountain dwellers. Not all health investments are equal; even a world-class hospital purposed to attract medical tourism from abroad is not the same as improving rural health services and access to local people in remote regions. Undefined intentions to transform the rural regions and agricultural sectors are also mentioned in the ZEESM planning documents. Although the urban-centrism of the proposals clearly favor high-density industrial development, Alkatiri acknowledges that forthcoming economic initiatives may be linked to the natural resource-based livelihoods that prevail in the district, including agriculture and fishing (Gabinete da Ex Primeiru Ministro Dr. Mari Alkatiri 2013). ${ }^{24}$ A government source notes that to become an industrialized region, the development priorities should be on commercial agriculture, tourism, and industrial centers with export potential (2014f:6).

Land dispossession by the state for mega-development construction projects has been strongly critiqued in recent years, in Timor-Leste as elsewhere (Centre on Housing Rights and Evictions 2007; Fitzpatrick, McWilliam, and Barnes 2012; Rede ba Rai 2013; Routledge 2003). The planned dispossession and evictions evident in ZEESM proposals carry a heavy, near-term ecological and socioeconomic price for Oecusse residents. In mid-2014, coastal Oecusse dwellers talked frequently about what structures they expected to be razed: their fences and some homes to accommodate the uniform road widening from the eastern border to town, a newly built school to make way for a high-rise hotel, the painstakingly built local university relocated to widen the roadway to the Lifau monument, and an entire village near the port to permit construction of "Heavy and chemical industry" as designated in the new zoning posted in town (Figure 4) and presented at public socialization meetings. These removals, begun in earnest by mid-2015,

\footnotetext{
${ }^{24}$ By mid-2014, Alkatiri had reportedly rejected three proposals from China to buy the entire ZEESM project because they did not meet the social goals embraced by the project (2014b). Investment proposals have included establishing a 400-hectare banana plantation for export to China, and a 100-hectare pineapple plantation in Oecusse (2014b).
} 
disrupt the hard-won stability of place among a population that experienced near-total displacement when they fled as refugees during the post-referendum violence in 1999.

The destruction of functional buildings will increase the pollution caused by new cement construction, as well as disposal problems for demolished structures and waste products in the district where "industrial and commercial waste management is nonexistent" (Zonas Especiais de Economia Social de Mercado de Timor-Leste (ZEESM T-L) 2013:46). The heavy chemical industry would be sited adjacent to one of the district's most extensive coral reefs. The two planned resort enclaves would divert water from already limited irrigated agricultural land in an ecologically fragile, water-scarce region (in Figure 4, note two green coastal areas on the western side). In addition, both the proposed "Paradise Beach Resort" (adjacent west of the seasonally flooded Tono river, featuring multiple hotels, a waterpark, and a 27-hole golf course) and the "Charming Eco Resort" (with its 18-hole golf course) are to be located on land currently farmed as productive rice fields owned and planted by a large number of smallholder families (Figure 6). The proposal to place such highly freshwater-dependent tourism infrastructure projects on sites where local people currently farm, in a context where most local communities still face periodic food shortages and chronic difficulties with household water access, demonstrates a remarkable lack of consideration for existing landholding practices and the resource access issues rural people face in Oecusse. The pervasive national lack of rigorous, meaningful Environmental Impact Assessments (EIA) extends to the ZEESM endeavor.

Very important for the people of Oecusse, the spatial re-ordering of their world also extends to the legal and administrative realms. It is this aspect that distinguishes ZEESM from most short-term development projects that may succeed or fail in a few years, with limited consequence. ZEESM has, in effect, become conflated with the regional government. Situating ZEESM within the national decentralization process, Alkatiri repeatedly states that having a new governance regime will allow Oecusse to solve issues locally, without the need for national consensus (RTTL 2013)—or elections, apparently, as the new governing body consists mostly of appointed officials (Presidency of the Council of Ministers 2015) — and that Oecusse will have special laws for immigration, trade, fiscal matters, banking systems, and "...everything. Just have a look to Singapore" (Gabinete da Ex Primeiru Ministro Dr. Mari Alkatiri 2013). In ZEESM publicity, Singapore is repeatedly held up as the model for developing Oecusse to be situated in the global economy, with the stated goal of capturing the medical tourism and higher education markets that Singapore currently attracts in the region and beyond. Oecusse's enclave location is deemed strategic to serve as a hub of trade collaboration and 'economic diplomacy', especially with Indonesia for agricultural products and value-added natural resource processing (Gabinete da Ex Primeiru Ministro Dr. Mari Alkatiri 2013).

To meet the ambitious goal of developing legal mechanisms that will clarify and permit land transactions in Oecusse, one of the first appointed members of the ZEESM Regional Authority is a former national director of the Land and Property Department. He held leadership roles in that department during Indonesian times through the UN era and early years of independence (Presidency of the Council of Ministers 2015) and has a long-standing interest in customary land ownership practices (Sousa Xavier 1997, 2001, 2003). If Oecusse develops a functional body of legal and administrative processes for land transactions, it will be unique at the national level. The risk Oecusse faces, with strong precedent from the few land laws passed in Dili, is that land policy could be made piecemeal, selectively privileging state rights and titles for urban areas while neglecting private and collective rights, with little attention to peoples' needs and priorities, customary practices, and livelihood realities in rural areas (Batterbury et al. 2015).

\section{Resorts on rice fields: prioritizing external inputs, resources, and services}

From its inception, ZEESM has been consistently outsider-focused in its priorities and concern for quality of service. Alkatiri spearheaded the ZEESM design from 2010, beginning by consulting multiple international bodies about potential involvement and investment potential; during 2013, a team of experts, including representation of Oecusse leaders, developed a 'Situation Analysis' with some Oecusse-based input. The ZEESM office and management team were initially based in Dili, ${ }^{25}$ awaiting the construction of a

\footnotetext{
${ }^{25}$ From 2014, the ZEESM office was located in Timor Plaza, Dili. La'o Hamutuk, which tracks government spending in the national transparency portal, points out that most of the early financial outlay for this initiative went toward
} 
suitable office complex in the enclave, as outlined in the proposals. The plan was revealed to the wider Oecusse public in an already formed state, a polished product to be socialized and justified to the population, rather than broadly shaped by input and priorities of Oecusse residents.

In a government television production about the one-week public presentation visit to Oecusse in late May 2013 (RTTL 2013), Alkatiri emphasizes that the city plan and design have been prepared by international (and especially Portuguese) technicians, including engineers, architects, economists, and others. The focus of the initial investment is on construction of some facilities that will largely serve outsiders' needs, centered around movement: public funds for constructing an international-standard airport and tourism facilities as well as expanding the newly completed port so materials and equipment can enter (Gabinete da Ex Primeiru Ministro Dr. Mari Alkatiri 2013; RTTL 2013; ZEESM 2013), alongside investment in roads, electrification, bridges, schools, and health systems. Private investment is intended for developing Oecusse's urban center and agricultural plantation crops for export (rather than, for example, broad-scale efforts to improve agrarian livelihoods in the uplands) (Gabinete da Ex Primeiru Ministro Dr. Mari Alkatiri 2013). Alkatiri is ambitious in seeing the project's influence on the rest of the country, calling the project a "development laboratory" that will be a model for the nation (Agência Lusa 2015, 2014f:5). Some project documents portray Oecusse visually at the center in a series of target-like concentric circles representing national economic development rippling out from the enclave; this is another form in which the project is crafted and envisioned to benefit people who are beyond Oecusse.

Large initial Timor-Leste government spending through ZEESM in the district is intended to signal to potential private investors that the government is committed to the success of this program (Gabinete da Ex Primeiru Ministro Dr. Mari Alkatiri 2013). Speaking to potential investors, Alkatiri portrays Oecusse people as hard workers: "You can really outsource some technology and know-how to Oecusse; they will do better than many other places" (Gabinete da Ex Primeiru Ministro Dr. Mari Alkatiri 2013). Alkatiri commented on the Special Zone's unique legal framework: "The immigration law, labor, fiscal, trades, everything you need, it has to be different than the normal one here in Timor-Leste, to be a bit more attractive for investors" (Gabinete da Ex Primeiru Ministro Dr. Mari Alkatiri 2013).

The project begins with investment in the infrastructure deemed essential for outsiders' access and comfort: airports, ports, multi-storey and high-end hotels, model Portuguese schools, and world-class universities and specialist model hospitals which will make Oecusse a destination for international academics, medical tourists, a flood of visitors to Lifau, and other guests (ZEESM 2013). The phrases "of international standard" or "international-quality" are peppered throughout most ZEESM presentations and publicity materials (RTTL 2013), indicating that the high aspirations are because of and for outsiders. Even the comment that ZEESM will be seeking 'Green City' designation (with the term always used in English) is directed pointedly toward international marketing of the ZEESM to attract potential foreign visitors, because this is what outsiders are seeking (RTTL 2013) — not for any benefits that special attention to environmental health and performance might bring to the local population. Similarly, one stated goal in public meetings is to make all of Oecusse's agricultural produce internationally certified as organic, for export potential and consumption by future urban immigrants-rather than focusing on the health benefits for local peoples' bodies and land. ZEESM statements justify massive efforts to provide water and electricity to the town region as essential to draw outside investors, activities from which local people will derive spillover benefits—not because having these public services would improve local life for Oecusse people. This focus on outsiders' needs is also evident in planning the late 2015 celebration of the Portuguese landing in Oecusse (Zonas Especiais de Economia Social de Mercado de Timor-Leste (ZEESM T-L) 2013:46).

The focus on outsiders' needs and interests both presumes and seems predicated on a separation or distinction between the local population and outsiders, even as it defines the new livelihoods that will be available and expected of Oecusse residents. For example, Alkatiri envisions the tourism potential to be increased if boat access to Dili improves from its current single ferry service, to two different ferries (one for cargo and one for passengers), and eventually adding a third for tourists (Gabinete da Ex Primeiru Ministro Dr. Mari Alkatiri 2013). Likewise, the proposed hospital built to attract foreign medical tourists will have an international section alongside a part where local people can receive free public health care; locals with

consultants, office rent in Dili, trips to regional urban centers, and vehicle purchases (http://www.laohamutuk.org/econ/Oecussi/ZEESMIndex.htm [accessed 12 January 2015]. 
serious illnesses not treatable in the local facilities could be referred to the international part of the hospital (RTTL 2013). In the May 2013 large public meeting, Alkatiri framed the need to increase Oecusse's agricultural production in terms of providing sought-after organic food for the anticipated burgeoning urban population, as well as for tourists and for export-neglecting to acknowledge that seasonal food shortages remain a reality for many of Oecusse residents. Despite awareness of persistent agricultural production challenges throughout the district (Zonas Especiais de Economia Social de Mercado de Timor-Leste (ZEESM T-L) 2013:30-33), local food security does not feature prominently in the public project rhetoric or near-term action plans.

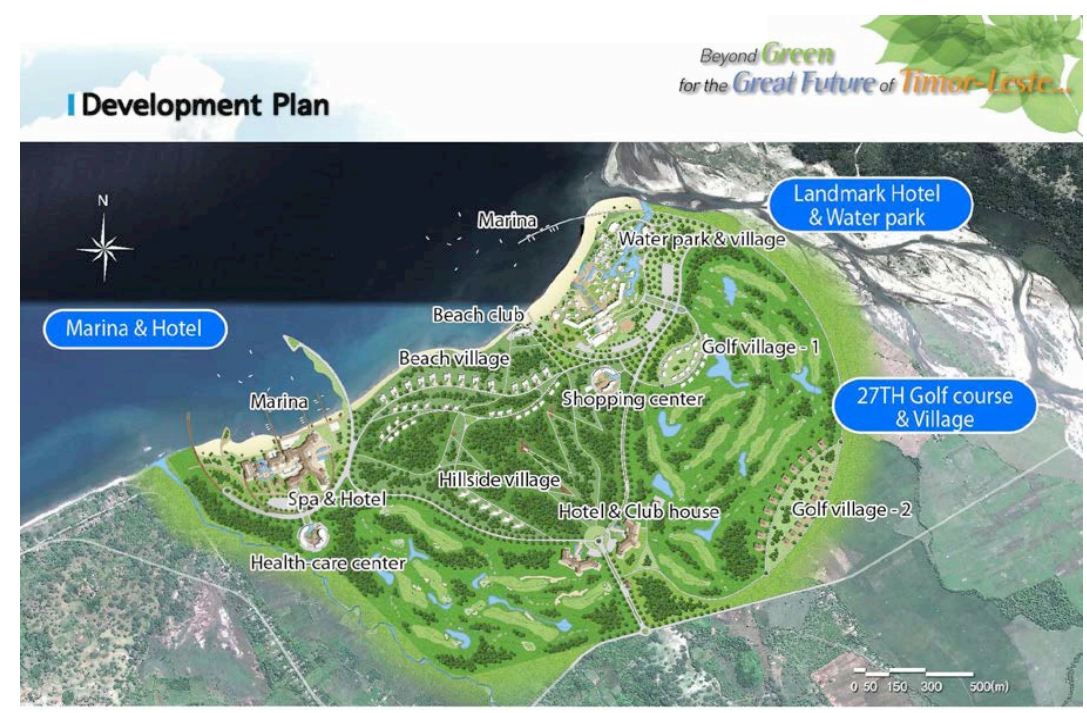

Figure 6: This gives design detail to the proposed Paradise Beach Resort pictured just west of the river in Figure 4. It is overlaid on existing wet rice fields, which are still visible at the edges of the planned resort. (Source: Kunil Engineering Co, Ltd; A proposal for Master Plan of Oecusse, January 24, $2014 . \quad$ Available at: http://www.laohamutuk.org/econ/Oecussi/ZEESMMasterPlanJan2014en.pdf, $\quad$ accessed 30 August 2014.)

\section{Oecusse's Olympics: development schemes as mega-events}

At the launch of ZEESM in 2015, the decades-long project is tasked with hosting a high-profile international event that is anticipated to attract many guests during the final months of the year. The ZEESM leadership has been given the job of executing this celebration, covered by public funding from the national budget; the rectified 2015 budget earmarked an additional US\$1.5 million allocated to ZEESM for the celebration (Autoridade Regional Administrativo Especial Oe-Cusse Ambeno 2015:18-19). Project documents discuss how the "500 Year Celebrations and Related Investments in Infrastructure and Services" activities are "not strategically linked to the other clusters, but do provide a test case for how coordinated effort can deliver results quickly" (Zonas Especiais de Economia Social de Mercado de Timor-Leste (ZEESM T-L) 2013:71). The action plan prioritizes building the airport, an electrical power station, coastal road widening and repair on the segment that will carry guests arriving at the eastern border as far west as the Lifau monument, hospital upgrades, hotel construction and management contracting, and tourism marketing. By early 2015, contracts and construction on several of the major infrastructure projects were underway (2015d, 2015b, 2015e, 2015c, 2015a, Bano 2014). The practice of building infrastructure and improving public facilities in haste for a large event's looming deadline is a common experience in locations hosting international sports competitions, fairs, and similar mega-events (Gaffney 2010; Vale and Gray 2013; Zimbalist 2015). The size and scale of the initiative has been highlighted from the outset; in an article entitled 'National Strategic Development Plan pushed ZEESM to start Mega Project', Alkatiri gives his standard public preface about how he got involved in the project: (then) Prime Minister Xanana Gusmão 
asked Alkatiri if he would lead this large, ambitious project (2014d). Alkatiri has also referred to the airport and roads components as mega-projects (Asosiasaun Radio Komunidade Timor-Leste 2014).

The time pressure of readying Oecusse for the 500-year anniversary celebration in November 2015 provided an opportunity — with a deadline-for setting in motion the significant political changes and economic outlays to enact the Constitutionally promised special governance regime for the enclave that has lain dormant for over eleven years, despite persistent efforts over the years by the initial ZEESM project manager and others to bring this matter before the Parliament. Legal support, national budget adjustments, and political handover occurred at an unusually rapid pace (2014c); with the anniversary celebration on the horizon, the national Council of Ministers approved an "accelerated legislative process relative to the ZEESM law" (2014e, my translation). For regions that are unable to muster support for needed basic infrastructure maintenance, Zimbalist $(2015: 47,121)$ notes that some of the major benefits of hosting a mega-event are overcoming political gridlock and partisan political stalemates to appropriate funding for infrastructure development. Zimbalist, however, cautions that use of public money for event-related construction can divert financial resources away from other deserving projects with longer-term or broaderbased benefits, and that hasty construction nearly always goes to external contractors using imported labor, which has been the case to date in Oecusse, with firms from Indonesia, Finland, and South Korea among those represented (2015a, 2015b, 2015c, 2015d, 2015e). This is one of the ways that capital intended for regional development "does not 'flow'...; it hops, neatly skipping over most of what lies in between. ...the 'movement of capital' here does not cover the globe; it connects discrete points on it" (Ferguson 2006:38)— from Timor-Leste's non-renewable petroleum resources to Jakarta or Seoul.

State-funded spatial reordering and land acquisition by the state are deemed foundational to the creation of the special economic zone, and are also emphasized as critical to the success of the 500-year celebration. In an April 2014 extraordinary session discussing twelve points related to ZEESM, the national Council of Ministers' first decision was to prioritize and to authorize the cadastral work required to make way for a range of construction projects deemed essential to the ceremony preparations (2014e; Ministry of Tourism 2015). In the absence of a national land policy and with only a few existing laws confirming the extent of state land claims, such acquisitions can only be made in favor of the state without clarity regarding private land rights, compensation, or other principles. Section IV, Article 26 of Law No. 3/2014 (published on 18 June 2014) has two clauses regarding land utilization that focus on the state's right to take land for purposes of development and to investors for economic activity; no mention is made of local residents' land rights or uses. The stated need to acquire and to clear land to make way for rushed construction projects (2014a; ZEESM 2013) can be used to justify hasty evictions, poor labor practices, and compromised product quality that would contravene the oft-stated ZEESM objectives of improving life and livelihoods in Oecusse for the long term (2014e, 2015c). The 2015 budget includes funding for land acquisition around transportation infrastructure, but the policies and regulations are not yet in place (Autoridade Regional Administrativo Especial Oe-Cusse Ambeno 2015:23).

Placing oversight for the anniversary celebration under ZEESM's watch situated the event within the larger project, and may conflate the two in policy or practice beyond 2015, effectively extending governance practices taken during the anniversary celebration to the wider project vision. Governance or policy matters may be set during the anniversary event preparation, but persist beyond the 'emergency period' of pre-event construction. As Zeffert (2012) explains, many regions and states frame the hosting of large events as:

...part of their economic development strategy, involving renewal of urban infrastructure and real estate investment. ... Host cities see mega events as key to repositioning themselves in the globalised market economy. Mega events are often the catalyst for new development, urban regeneration, upgrading and beautification projects, and the adoption and implementation of housing plans. They attract public and private investment. Host cities see unprecedented levels of construction in inner and peripheral areas. This generates new business and employment opportunities, increased traffic, demand for services and public transport, as well as changes in population demographics, cost of living, environment and air quality. Some of this may have positive impacts on citizens' rights, including increased access to work and general economic benefit. However, the negative impacts of mega events on citizens' rights, and on the city's capacity to realise citizens' rights, are more numerous. 
Zimbalist (2015) gives a sobering, well-documented account of the risks and realities of regions hosting mega-events: with few exceptions, the economic, social, and political outcomes from the events fall far short of the overly optimistic claims used to attract the event in the first place, and long-term outcomes are not positive. While mega-events give cities an opportunity to refine and to present a polished image to a broad audience (Flyvbjerg 2014; Gold and Gold 2008; Tomlinson, Bass and Bassett 2011), experience demonstrates that this effect is usually short-lived. Temporary or permanent displacement to make way for the accelerated development infrastructure precipitated by mega-events has been a major, chronic issue surrounding them (Gaffney 2010; Gold and Gold 2008; Vale and Gray 2013; Zimbalist 2015). In addition, a rushed timeline rarely favors high-quality construction or broad civic participation in development initiatives, potentially setting precedents that may be difficult for ZEESM to overcome.

The most visible, initial ZEESM focus is on externally oriented hard infrastructure and industrial developments, rather than on building human capabilities or mobilizing local resources (La'o Hamutuk 2012). On the ZEESM.com web page in late 2015, the 'Projects' listed include only planned buildings and capital investments: the international airport; the Hotel ZEESM Timor-Leste; a tourism and cultural information center; a multi-story RAEOA administrative building; the expansive ZEESM villa and residential complex; a seafront park with free wifi; a ferry boat; a power station; an amphitheater-style Lifau Monument "for the celebration of the 500th anniversary of the arrival of Portuguese navigators and missionaries in Lifau-Oé-Cusse, a fact that marks the beginning of construction of the new identity of Timor Leste"; $50 \mathrm{~km}$ of coastal urban roads, especially from Oecusse's eastern Indonesian border to the Lifau Monument; and a 380-meter bridge along the coastal road. ${ }^{26}$ Notably absent are any of the locally hoped-for initiatives in education, technical skill-building, healthcare access, and other spheres; even the infrastructure for the vaunted health facilities and university for which ZEESM promises the district will become known are not present in this phase. Such infrastructure-centrism predisposes the project to certain development models that favor administrative interests in centrally managed solutions above others. For example, prioritizing high-rise, five-star hotel construction meant to house a brief one-time influx of guests for the 2015 celebration neglected alternative approaches to housing anticipated short-term visitors in ways that distribute benefits among the local population with longer-term benefits, for example in providing incentives to build and furnish guest rooms and in training host families for local homestays and community-based tourism (Tolkach and King 2015). By starting off with a mega-event, ZEESM faces specific challenges to distinguish its development model from any other fantastical scheme that fizzles out when the first flush of financial resources are burnt through a flurry of high-profile publicity activities and feasibility plans. After launching ZEESM with the hype of a massive event focused on infrastructure construction, it may be a challenge to keep the vision and momentum of a long-term, comprehensive governance plan in peoples' minds.

\section{Conclusion: persistence of misdevelopment and its risks for the Oecusse population}

The array of challenges to improving rural peoples' lives durably in remote regions is daunting. Even well-intentioned leaders face the chronic temptation to erase and replace: to bypass the unglamorous work of building upon the messy complexities that exist, and instead seek to supplant what is with a cleaner, simpler vision for what could be. Grandiose development schemes rarely meet their publicized objectives; and yet, many leaders in Timor as elsewhere demonstrate an unfounded optimism that utopian projects will actually work to reduce endemic poverty and to improve the lives of ordinary people, despite overwhelming evidence to the contrary (Dove and Kammen 2001; Ferguson 1997; Kammen 2009). Many observers of Timor-Leste's strategic investment choices wonder, as did one reviewer for this article, "Why is the government of a country comprised of [largely] subsistence farmers obsessed with glitzy prestige projects at the expense of more pressing needs such as health and agriculture?" ${ }^{27}$ Internal political motivations and aspirations to achieve regional recognition are parts of the explanation (Kammen 2015; La'o Hamutuk 2014), but the sheer appeal of the apparent relative ease of overwriting present difficulties with novelty should not be discounted.

\footnotetext{
${ }^{26}$ These are pictured on the webpage http://zeesm.com/category/projects, accessed 10 October 2015.

${ }^{27}$ The www.laohamutuk.org website has extensive financial and political analysis that informs answers to this question.
} 
Magic bullets are shiny: national leadership and international aid agencies alike are easily captivated by glossy, too-good-to-be-true projects, with their expansively appealing if unrealizable promises.

Overly aspirational development plans may not only result in a failure to improve life for local residents, but such plans may also lead to failure in this area. Some degree of utopian idealism is understandable among Timor-Leste leaders. The nation achieved what long appeared to be an unlikely independence from a powerful regime, and the intractability of enduring socioeconomic problems may push idealistic leaders to seek dramatic, other-worldly solutions in a context where very few enjoy uninterrupted material security. But projects of massive proportions are more likely to falter, precisely because local people with long experience of development projects that over-promise and under-deliver lack confidence in the realization of actual, enduring positive outcomes from a proposed mega-project. Where local perceptions recognize that a project is too far-fetched to achieve its stated outcomes, many people take advantage of short-term benefits that can be gleaned, thus contributing to the delay or non-completion of the stated project. Underperformance backfires: failure to deliver on promises undermines peoples' confidence in government to achieve any outcomes, and they may resort to treating visionary, ambitious projects just like cash-for-work programs. This can incentivize slow progress and discourage any final accomplishments, since these would end the income stream. In 2014, some Oecusse residents pointed to the ill-placed, newly installed electric poles with no wires, and indicated that they were badly located-but that this fact was of no import, because soon another salaried work contract would be issued for the poles to be relocated, and that contract-not the electrification itself-was the real, tangible benefit of the initiative. This is why reasonably-scaled and targeted initiatives may be more likely to result in the stated improvements than over-ambitious ones.

Is there any harm in a simplification-seeking state approach to development? Imagine that the ZEESM program were to be implemented without the most immediate problematic aspect to Oecusse people, that of displacing long-time residents from their homes and fields to make way for industrial zones, resorts, and infrastructure built primarily with external beneficiaries in mind. Presume for a moment that the siting of built projects were shifted to use the tracts of uninhabited and relatively barren land that dot the coastline rather than placing resorts on local peoples' productive rice fields. Would there be any harm, then, in Oecusse receiving a fancy airport, additions to its brand-new port, high-rise hotels that will likely stand empty, and short stretches of decently paved roads? While these investments do not generate much enduring local employment in and of themselves, is their construction not at least neutral in the grand scheme of things? These questions might reasonably be asked by a population conditioned to low development expectations through experiencing decades of fantastical schemes and ill-fated projects.

The problem is that misdevelopment is not benign. Initiatives that favor one region or sector-for example, coastal industrial development-necessarily define priorities and cast a vision for what constitutes an acceptable future. In the case of ZEESM, this seems to be a focus on a generic 'urban package', the success of which will be measured by outsiders' willingness to invest in facilities for foreign tourism and industrial interests (Ministry of Tourism 2015). And where the planned US\$1.36 billion of public investment draws from the national petroleum savings of a small nation with few promising long-term economic prospects (Zonas Especiais de Economia Social de Mercado de Timor-Leste (ZEESM T-L) 2013), the opportunity costs of squandered national wealth are large. Even more tragic than wasted money is the diversion of human resources away from addressing local peoples' priorities and toward satisfying the luxury desires of hypothetical foreign visitors. The massive distraction of glossy mega-projects takes a high toll on the ability of dedicated Timorese leaders to focus their time, creativity, and talents on planning and bringing about fundamental human and economic improvements to a region where the majority of residents still suffer from chronic deprivation of basic needs. Infrastructure construction is not development; it does not in and of itself constitute improved lives for citizens.

Two chief risks of misdevelopment in Oecusse lie in closing off, rather than in expanding, future options. First, investing heavily in the few externally oriented coastal projects represents a choice against making near-term improvements in the rest of the district, which are the remote, mountainous communities where the vast majority of the population lives and which are in most critical need of improvements in transportation, education, and health services. There appears to be little flexibility or responsiveness built into the plan to mobilize public money to also serve these central needs as identified and publicly expressed by the largely agrarian, rural local population. If foreign involvement is delayed or does not materialize, can the public funding be used toward the basic rural water projects, more extensive rural health services, better 
educational access, agricultural extension, paving the existing core two-lane roads, and attention to rural transportation priorities that were clearly and repeatedly requested by Oecusse residents in the large May 2013 meeting? If the high-stakes ZEESM project fails to take off, for any of the realistic reasons a team of Oecusse experts listed soberly in the Situation Analysis, it is not likely that Oecusse would get a second chance to attract attention and resources on this scale (Zonas Especiais de Economia Social de Mercado de Timor-Leste (ZEESM T-L) 2013).

A second risk is that the 2014 and 2015 legislation that effectively excised Oecusse from national governance structures and the normal budget may increase the district's vulnerability if it does not have parity of access to recourse in the event of political neglect or abuses by elites and outside interests, or potentially to national-level assistance in the event of major disaster or economic hardship. Given the swiftness with which the legislation was produced and passed, perhaps it may be undone just as easily should the need arise in the future. As ZEESM is just the latest iteration of a long-standing tradition of political isolation for the OecusseAmbeno region, this may not compromise Oecusse's status in the near term; while the enclave's ties to Dili have strong sentimental and political importance, they have been of limited practical utility to the improvement of everyday life for Oecusse people. A development scheme that explicitly removes Oecusse from the minimal legal protections afforded by national labor laws for the purposes of attracting investment may be one that places local people at risk, especially if their special legal and economic status-coupled with geographic challenges that complicate access-further reduce the enclave's visibility to accountability mechanisms.

Scott (1998) explained that what doomed many well-intentioned high modernist projects was the failure of planners to understand local, practical knowledge, and their naiveté about the spontaneous nature of human society that defies rigid standardization at every turn. Overconfidence in technical progress can be a distraction from facing and addressing the resource realities of a place (Flyvbjerg 2014). To reduce the risks of high modernism, Scott recommends the following: Take small, incremental steps, not large ones. Ensure adaptation and reversibility to plans once reality demonstrates why the plans are not feasible, or do not progress as planned. Allow for human inventiveness that may improve plans. Be open to improvisation.

Oecusse is famous for its distinctive history, not only of alighting clergy long ago but also for strong, autonomous leaders who should be a critical resource in regional development (Hägerdal 2012; Meitzner Yoder 2007a, b). District governance system and economic development initiatives can build on Oecusse's human resource strengths and existing institutions, rather than erasing them in favor of generic structures derived from international templates. Giving more, not less attention to place could enable the rural sectors to flourish alongside new town-based opportunities that may take root, and avoid exacerbating the existing disparities in coastal and mountain services. The district government can foster Oecusse's own cultural distinctiveness, not only of the "song and dance variety" (Li 2000) that may be treated as tourism magnets, but also understanding or recognizing Oecusse peoples' cultural practices including customary land claim mechanisms, local settlement patterns, and even the decision to make their lives in the mountains. Early stages of the ZEESM project have resulted in more fear of displacement than tangible benefits for coastal residents, and disinterest on the part of mountain dwellers who see little relevance of this project to their lives and needs. How can ZEESM improve its chances of having positive, lasting impacts on the lives of Oecusse residents? Promoting realistic socio-economic initiatives that build upon the strengths and priorities of local people, rather than supplanting them with aspirational distractions of mega-projects, would be well worth additional consideration.

\section{References}

2014a. Babo ha funsionariu DNTT deskuti implementasaun ZEEMS. Timor Post, 13 June 2014.

2014b. Development of Oecussi enclave, Timor-Leste, begins in July. Macau Hub, 25 June 2014.

2014c. Parlamentu nasional aprova final global lei rejiaun espesial Oe-Cusse Ambeno. Bulletin Governu, May 2014, 7.

2014d. PEDN dudu ZEESM hahu mega projeitu. Business Timor, 28 April 2014. [Accessed 31 December 2014].

2014e. Preparasaun tinan 500 Portugal tama Timor, KM hasai pontu 12 ba ZEEMS. Business Timor, 28 April 2014 [Accessed 31 Dec 2014]. 
2014f. ZEESM, Modelu dezenvolvimentu inovativo. Bulletin Governu, May 2014, 4-6.

2015a. Governu gasta milaun U\$32 ba sentral elektrica Oe-Cusse. Oecusse Post, January 2015, 4.

2015b. MAP gasta tokon U\$11 ba irigasaun Tono. Oecusse Post, January 2015, 1, 15.

2015c. Projeitu 4 afeita ba suku 5. Oecusse Post, January 2015, 4.

2015d. Timor-Leste chega a acordo com empresa indonésia para aeroporto Oe-cusse. 23 February 2015. ]Accessed 14 March 2015].

2015e. ZEESM gasta tokon U\$90 hari ponte Noe Fefan. Oecusse Post, January 2015, 5.

Agência Lusa. 2015. Projecto de OeCusse deve ser referência para todo o país - Mari Alkatiri.

Anuno, J., and J. Muni Salu. 2003. Undang-undang status khusus enclave Oe-cusse/Ambeno, Maret 2003: Rencana Pembentukan Daerah Administratif Khusus Oe-cusse. Oecusse, East Timor.

Asosiasaun Radio Komunidade Timor-Leste. 2014. EProjectu piloto ba zona ekonomi especial sei implementa iha Oe-cusse.

Autoridade Regional Administrativo Especial Oe-Cusse Ambeno. 2015. Orsamentu rektifikativu aprovadu 2015 RAEOA-ZEESM Livru-3B. Edited by Ministeriu Finansas. Dili.

Bano, A. 2014. ZEESM, Special economic zone of social market economy: Oecusse pilot project. Presentation at National University of Timor-Leste, 7 July 2014. Dili.

Bano, A. and E. Rees. 2002. The Oecussi-Ambeno enclave: what is the future for this neglected territory? Inside Indonesia 71:20-22.

Batterbury, S.P.J., L.R. Palmer, T.R. Reuter, D. do Amaral de Calvalho, B. Kehi, and A. Cullen. 2015. Land access and livelihoods in post-conflict Timor-Leste: no magic bullets. International Journal of the Commons 9 (2): 619-647.

Boxer, C.R. 1947. The Topasses of Timor. Institut voor de Tropen. Afdeling Culturelz en Physische Anthropologie. n.p.: Koninklijke Vereeniging Indisch Institut Mededeling no. LXXIII No. 24.

Centre on Housing Rights and Evictions. 2007. Fair play for housing rights: mega-events, Olympic games and housing rights. Geneva: COHRE.

Correia, S. 1933. Timor. Boletim da Sociedade Luso-Africana do Rio de Janeiro 5:61-63.

Daschbach, R. 1987. Three guru agamas. Divine Word Missionaries Summer 1987:8-10.

Daschbach, R. 1992. Ambeno: Bagaimana rupamu doeloe. In G. Neonbasu (ed.) Agenda budaya pulau Timor (2): 42-49. Atambua, West Timor: Komisi Komunikasi Sosial Provinsi SVD Timor.

Dores, R das. 1901. Apontamentos para um diccionario chorographico de Timor. Boletim da Sociedade de Geographia de Lisboa 19 (7-12):763-826.

Dove, M.R. and D.M. Kammen. 2001. Vernacular models of development: an analysis of Indonesia under the "New Order". World Development 29 (4):619-639.

Durand, F. 2002. Timor Lorosa'e, pays au carrefour de l'Asie et du Pacifique: un atlas géo-historique. Marne-la-Vallée: Presses Universitaires de Marne-la-Vallée.

Ferguson, J. 1997. The anti-politics machine: "development," depoliticization, and bureaucratic power in Lesotho. Minneapolis: University of Minnesota Press. Original edition, [1990]. summary

Ferguson, J. 2006. Global shadows: Africa in the neoliberal world order. Durham: Duke University Press.

Ferreira, J.G. 1902. Calculo approximado da população da parte Portugueza de Timor, Feito en 1882. Boletim da Sociedade de Geographia de Lisboa 20 (10):129-131.

Fitzpatrick, D., A. McWilliam, and S. Barnes. 2012. Property and social resilience in times of conflict: land, custom and law in East Timor. London: Ashgate.

FLD. 2013. Masterplan zona especial de economia social de mercado de Timor-Leste [ZEESM T-L]. Dili: Lusitania Foundation for University and Entrepreneurial Development. http://www.laohamutuk.org/econ/Oecussi/MasterPlanFLDMar2013.pdf [accessed 30 August 2014].

Flyvbjerg, B. 2014. What you should know about megaprojects and why: an overview. Project Management Journal 45(2): 6-19.

Fox, J.J. 2000. Tracing the path, recounting the past: historical perspectives on Timor. In J.J. Fox and D.B. Soares (eds.). Out of the ashes: destruction and reconstruction of East Timor. Canberra: ANU E Press. Pp.1-27. 
Gabinete da Ex Primeiru Ministro Dr. Mari Alkatiri. 2013. Special zones of social market economy: pilot location Oecusse. Film. Released 9 September 2013. Dili: ZEESM. http://zeesm.com/category/videos [accessed 11 January 2015].

Gaffney, C. 2010. Mega-events and socio-spatial dynamics in Rio de Janeiro, 1919-2016. Journal of Latin American Geography 9 (1):7-29.

Gold, J.R. and M.M. Gold. 2008. Olympic cities: regeneration, city rebranding and changing urban agendas. Geography Compass 2(1): 300-318.

Gunn, G.C. 1999. Timor Loro Sae: 500 years. Macau: Livros do Oriente.

Hägerdal, H. 2012. Lords of the land, lords of the sea: conflict and adaptation in early colonial Timor, 16001800. Leiden: KITLV.

Kammen, D. 2009. Fragments of utopia: popular yearnings in East Timor. Journal of Southeast Asian Studies 40 (2):385-408.

Kammen, D. 2015. Timor-Leste and ASEAN. In The third ASEAN reader. Singapore: Institute of Southeast Asian Studies. Pp. 54-58.

Kingsbury, D. 2012. Community development. In D. Kingsbury, J. McKay, J. Hunt, M. McGillivray and M. Clarke (eds.) International development: issues and challenges. New York: Palgrave Macmillan. Pp. 245-271.

Kunil Engineering Co., Ltd. 2014. A proposal for master plan of Oecusse (January 24, 2014). http://www.laohamutuk.org/econ/Oecussi/ZEESMMasterPlanJan2014en.pdf [accessed 2 February 2015].

La'o Hamutuk. 2012. Infrastructure for Timor-Leste's people. http://laohamutuk.blogspot.com/2012/07/infrastructure-for-timor-lestes-people.html] [Accessed 15 October 2015].

La'o Hamutuk. 2014. Special economic zone in Oecusse. Last modified 31 July 2014. Accessed 15 October. http://www.laohamutuk.org/econ/Oecussi/ZEESMIndex.htm

La'o Hamutuk. 2015. 2015 General state budget. Last modified 16 March 2015. http://www.laohamutuk.org/econ/OGE15/14OGE15.htm [Accessed 24 March 2015].

Li, T. Murray. 2000. Articulating indigenous identity in Indonesia: resource politics and the tribal slot. Comparative Studies in Society and History 42 (1):149-179.

Martinho, J.S. 1945. Problemas administrativos de colonizacão da Provincia de Timor. Pôrto: Livraria Progredior.

McWilliam, A. and E.G. Traube (eds.) 2011. Land and life in Timor-Leste: ethnographic essays. Canberra: ANU E Press.

Meitzner Yoder, L.S. 2007a. Hybridising justice: state-customary interactions over forest crime and punishment in Oecusse, East Timor. The Asia Pacific Journal of Anthropology 8 (1):43-57.

Meitzner Yoder, L.S. 2007b. The tobe and tara bandu: a post-independence renaissance of forest regulation authorities and practices in Oecusse, East Timor. In R. Ellen (ed.) Modern crises and traditional strategies: local ecological knowledge in island Southeast Asia. New York: Berghahn. Pp. 220-237.

Meitzner Yoder, L.S. 2011a. Political ecologies of wood and wax: Sandalwood and beeswax as symbols and shapers of customary authority in the Oecusse enclave, Timor. Journal of Political Ecology 18:11-24.

Meitzner Yoder, L.S. 2011b. Tensions of tradition: making and remaking claims to land in the Oecusse enclave. In A. McWilliam and E.G. Traube (eds.) Land and life in Timor-Leste: ethnographic essays. Canberra: ANU E Press. Pp. 187-216.

Ministry of Tourism. 2015. Ministry of Tourism begins construction in Oecusse. 25 January 2015. Accessed 15 February 2015. Dili: Ministry of Tourism. http://turismo.gov.tl/en/content/detail/ministry-oftourism-begins-construction-in-oecusse- [accessed 15 February 2015].

National Statistics Directorate (NSD) [Timor-Leste], Ministry of Finance [Timor-Leste], and ICF, and Macro. 2010. Timor-Leste demographic and health survey 2009-10. Dili: NSD [Timor-Leste] and ICF Macro.

NDPEAC and MoPF. 2004. Lessons learned: the Community Empowerment and Local Governance Project (CEP). Dili: National Directorate of Planning and External Assistance Coordination (NDPEAC) of the Ministry of Planning of Finance (MoPF), Democratic Republic of Timor-Leste. 
NSD and UNFPA. 2011. Population and housing Census 2010: social and economic characteristics. Volume 3. Edited by National Statistics Directorate and United Nations Population Fund. Dili.

Oliveira, Luna de. 1949. Timor na história de Portugal. III vols. Vol. I. Lisboa: Agência Geral das Colónias.

Oliveira, Luna de. 1950. Timor na história de Portugal. III vols. Vol. II. Lisboa: Agência Geral das Colónias.

Ormeling, F. J. 1956. The Timor problem: a geographical interpretation of an underdeveloped island. Groningen and The Hague: J. B. Wolters and Martinus Nijhoff.

Parada, Norberto Augusto. 1974. Timor. In Teixeira M. (ed.) Macau e a sua diocese. Macau: Tipografia da Missão do Padroado. Pp. 552-568.

Pereira, Ágio. 2015. Council of Ministers to meet in Oe-Cusse Ambeno. Edited by Spokesperson of Constitutional Government Media Release. Dili, Timor-Leste. http://timor-leste.gov.tl/wpcontent/uploads/2015/01/Council-of-Ministers-to-meet-in-Oe-Cusse-Ambeno.pdf [Accessed 16 January 2015].

Presidency of the Council of Ministers, V Constitutional Government. 2015. Extraordinary meeting of the Council of Ministers of 23rd of January 2015. http://timor-leste.gov.tl/?p=11123\&lang=en\&lang=en. [Accessed 24 January 2015].

Procuradoria da Diocese da Dili em Lisboa. 1956. Introdução. In Lasi Sarani. Lisboa: Procuradoria da Diocese da Dili.

Rede ba Rai. 2013. Land registration and land justice in Timor-Leste: culture, power and justice. Dili: Haburas Foundation.

Republica Democratica de Timor-Leste. 2011. Timor-Leste strategic development plan 2011-2030. Dili: RDTL.

Routledge, P. 2003. Voices of the dammed: discursive resistance amidst erasure in the Narmada Valley, India. Political Geography 22 (3):243-270.

RTTL, Produsaun. 2013. Programa debate no konsulta publico master plan zona especial de economia social de mercado de TL, Projecto Piloto Distrito Oecusse. Film, 59:30 minutes. http://www.zeesm.com/zeesm-official-video [accessed 2 February 2015].

Scott, J. C. 1998. Seeing like a state: how certain schemes to improve the human condition have failed. New Haven and London: Yale University Press.

Sousa Xavier, P. de. 1997. Studi tentang hukum pertanahan adat Timor Timur di Kecamatan Uato Carbau Kabupaten Viqueque. Diploma IV, Jurusan Perpetaan, Sekolah Tinggi Pertanahan Nasional.

Sousa Xavier, P de. 2001. Land rights and sustainable development in East Timor. Conference on Sustainable Development in East Timor, Dili, East Timor, 25-31 January 2001.

Sousa Xavier, P de. 2003. Oral and Powerpoint(r) presentation to socialize the first land law. Oecusse, East Timor: Direç̧ão de Terras e Propriedades.

Taylor, J.G. 1999a. East Timor: the price of freedom. London and New York: Zed Books.

Taylor, P.J. 1999b. Modernities: a geohistorical interpretation. Minneapolis, MN: University of Minnesota Press.

Teixeira, M. (ed.) 1974a. Macau e a sua diocese. Macau: Tipografia da Missão do Padroado.

Teixeira, M. 1974b. Pe. João dos Reis Martins. In Teixeira, M. (ed.) Macau e a sua diocese. Macau: Tipgrafia da Missão do Padroado. Pp. 249-257.

Tolkach, D. and B. King. 2015. Strengthening community-based tourism in a new resource-based island nation: why and how? Tourism Management 48 (June):386-398.

Tomlinson R, O. Bass and T. Bassett. 2011. Before and after vuvuzela: identity, image and mega-events in South Africa, China and Brazil. South African Geographical Journal 93 (1):38-48.

United Nations Development Program. 2002. East Timor human development report 2002: Ukun rasik r'an; East Timor - the way ahead. Dili: UNDP.

Vale, L. and A. Gray. 2013. The displacement decathlon: Olympian struggles for affordable housing from Atlanta to Rio de Janeiro. Places. https://placesjournal.org/article/the-displacement-decathlon/. [Accessed 20 December 2014].

Vaquinhas, J. dos Santos. 1883. I: Timor. Boletim da Sociedade de Geographia de Lisboa 4 (7):307-328. 
Wallis, J. and P. Myat Thu. 2013. In Timor, a new house does not make a home. http://ips.cap.anu.edu.au/news-events/all-stories/timor-new-house-does-not-make-home. [Accessed 10 October 2015].

ZEESM. 2013. Mensagen Dr. Mari Alkatiri kona ba master plan (ZEESM) Oecusse. Film. Released May 2013. 9 minutes. Dili: ZEESM.

http://www.laohamutuk.org/econ/Oecussi/AlkatiriMsgMay2013te.mp4. [Accessed 2 February 2015].

Zeffert, H. 2012. Private vs. public: mega events, human rights and the London Olympics. Assemble. http://assemblepapers.com.au/2012/08/03/privately-public-mega-events-human-rights-and-thelondon-olympics/ [Accessed 20 December 2014].

Zimbalist, A. 2015. Circus maximus: the economic gamble behind hosting the Olympics and the World Cup. Washington, D.C.: Brookings Institution.

Zonas Especiais de Economia Social de Mercado de Timor-Leste (ZEESM T-L), Projecto piloto distrito Oecusse. 2013. Special economic zones of social market economy: first steps towards a new Oecusse. 